University of Nebraska - Lincoln

DigitalCommons@University of Nebraska - Lincoln

\title{
Effect of Foliar Applied Plant Elicitors on Microbial and Nematode Populations in the Root Zone of Potato
}

\author{
H. P. Collins \\ United States Department of Agriculture-Agricultural Research Service, hcollins@pars.ars.usda.gov \\ D. A. Navare \\ United States Department of Agriculture-Agricultural Research Service \\ E. Riga \\ Washington State University \\ F. J. Pierce \\ Washington State University, fran.pierce@gmail.com
}

Follow this and additional works at: https://digitalcommons.unl.edu/usdaarsfacpub

Part of the Agricultural Science Commons

Collins, H. P.; Navare, D. A.; Riga, E.; and Pierce, F. J., "Effect of Foliar Applied Plant Elicitors on Microbial and Nematode Populations in the Root Zone of Potato" (2006). Publications from USDA-ARS / UNL Faculty. 526.

https://digitalcommons.unl.edu/usdaarsfacpub/526

This Article is brought to you for free and open access by the U.S. Department of Agriculture: Agricultural Research Service, Lincoln, Nebraska at DigitalCommons@University of Nebraska - Lincoln. It has been accepted for inclusion in Publications from USDA-ARS / UNL Faculty by an authorized administrator of DigitalCommons@University of Nebraska - Lincoln. 


\title{
Effect of Foliar Applied Plant Elicitors on Microbial and Nematode Populations in the Root Zone of Potato
}

\author{
H. P. Collins and D. A. Navare \\ United States Department of Agriculture-Agricultural Research Service, \\ Vegetable and Forage Crops Research Unit, Prosser, Washington, USA \\ E. Riga \\ Washington State University, Irrigated Agricultural Research and \\ Extension Center, Prosser, Washington, USA

\section{F. J. Pierce} \\ Washington State University, Center for Precision Agricultural Systems, \\ Irrigated Agricultural Research and Extension Center, Prosser, \\ Washington, USA
}

\begin{abstract}
Systemic acquired resistance (SAR) is a process whereby a plant that successfully resists a pathogen becomes highly resistant to subsequent infection not only by the original pathogen but also by a wide variety of pathogens. Most SAR research has focused on resistance in leaves, so much less is known about the effectiveness of foliar applications of SAR compounds in the protection of plant roots and associated microorganisms in soil. This study was conducted to determine if foliar SAR-inducing applications (BTH or harpin) negatively impact the potato root system beneficial rhizosphere microbial populations and activity or influence pathogenic nematode populations. Foliar applications of benzo $(1,2,3)$ thiadiazole-7carbothioic acid S-methyl ester (BTH) and the microbial protein harpin applied in various combinations, timings, and rates showed no effects on microbial biomass, culturable bacteria, Pseudomonas populations, or N-mineralization potentials over 2 years. No stimulatory or inhibitory effects on major bacterial populations were
\end{abstract}

Received 16 May 2005, Accepted 16 September 2005

Address correspondence to Harold P. Collins, USDA-ARS, Vegetable and Forage Crops Research Unit, 24106 North Bunn Road, Prosser, Washington 99350, USA. E-mail: hcollins@pars.ars.usda.gov 
observed, indicating that SAR induction does not have a negative effect on general microbial populations or activities. BTH and harpin both reduced the numbers of lesion nematodes (Pratylenchus spp.) by potato harvest. BTH reduced root knot nematodes, Meloidogyne chitwoodi at the end of the season. In addition, BTH and high-dose harpin (applied at the $4 \times$ rate) reduced the nematode infection index in comparison to the control. The SAR elicitors increased the population densities of nontarget free-living nematodes in the soil compared to the control. Potato yields were not affected by plant elicitors but BTH and harpin both reduced the number of culled potatoes $26 \%$ compared to the control. Future studies are designed to determine if these plant elicitors have any direct effect on rhizosphere diversity or if plants with active defense pathways alter carbon flow and root exudates into the soil.

Keywords: BTH, harpin, microbial populations, nematodes, pathogens, plant elicitors of SAR

\section{INTRODUCTION}

Systemic acquired resistance (SAR) is a physiological "state of enhanced capacity" elicited by biotic or abiotic environmental stimuli that activate a plant's immune defenses (Vallad and Goodman 2004). Plants exhibiting SAR have enhanced resistance against a variety of pathogens. SAR can be induced by challenging a plant with virulent, avirulent, and nonpathogenic microorganisms or artificially with certain chemicals (Sticher, Mauch-Mani, and Metraux 1997). Numerous compounds have been shown to be elicitors of SAR, including salicylic acid, 2,6-dichloro-isonicotinic acid (INA), benzo $(1,2,3)$ thiadiazole-7-carbothioic acid S-methyl ester (BTH) [also known as acibenzolar-S-methyl], and the microbial protein harpin. Salicylic acid (SA) is a key regulator of SAR, and studies with mutants disrupted in SA signaling show that such plants are more susceptible to many diseases (Dempsey, Shah, and Klessig 1999; Klessig et al. 2000). BTH is considered a functional analog of SA and elicits the SAR response in the leaves of solanaceous plants against a wide variety of fungal and bacterial pathogens under field conditions (Abbasi et al. 2002; Csinos et al. 2001; Matheron and Porchas 2002). Harpin is a protein produced in nature by several bacterial plant pathogens (e.g., Erwinia amylovora). Unlike traditional pesticides, SAR activators do not act directly on the disease organism. They enhance disease resistance by activating multiple defense signal transduction pathways leading to activation of defense genes in the host plant and have been shown to be effective in enhancing resistance in numerous crops and plants (Lawton et al. 1996; Vallad and Goodman 2004). The success achieved by a number of the SAR compounds suggests that they may be valuable tools in the context of integrated pest management that reduces the use of conventional pesticides in favor of these nonbiocidal, nontoxic, low-rate products (Gozzo 2003).

Most SAR research has focused on resistance in leaves, so much less is known about the effectiveness of foliar applications of SAR compounds in 
the protection of plant roots. Similarly, little is know about the effects of foliar SAR treatments on the natural soil microflora. Traditional pesticide applications are often nonselective, not only impacting pathogenic organisms but also having undesirable effects on beneficial microflora. Conversely, little is known about the consequences of salicylic acid-mediated defense gene induction on the rhizosphere. This study was conducted to determine if foliar SAR (BTH or harpin) applications induce a response in the potato root system that influenced rhizosphere microbial populations and activity or pathogenic nematodes.

\section{METHODS AND MATERIALS}

A field study was conducted in 2002 and 2003 at the Washington State University Irrigated Agriculture Research and Extension Center located in lower Yakima Valley in eastern Benton County. The experimental area consisted of soils mapped as the Warden Silt loam that, under an average annual rainfall of $160 \mathrm{~mm}$, require irrigation for crop production. In 2001, the 1.2-ha field was cropped to spring barley (Hordeum vulgare) with no irrigation applied. In 2002, a 3-year crop rotation of winter wheat/field corn/ potato (Triticum aestivum/Zea mayes/Solanum tuberosum) was established in three 0.4-ha blocks. Within the potato blocks for the 2002 and the 2003 growing season (following corn), a field experiment was installed as a randomized complete block with four replications of various SAR applications with experimental units consisting of $15 \mathrm{~m} \times 5 \mathrm{~m}$ plots with six rows of potatoes (var. Russet Burbank) planted on 0.87-m row spacing. Plant elicitor treatments in 2002 included foliar applications of two SAR-inducing compounds, BTH at a rate of $0.14 \mathrm{~g} \mathrm{~L}^{-1}$ and harpin at rates of $0.67 \mathrm{~g} \mathrm{~L}^{-1}$ and $2.01 \mathrm{~g} \mathrm{~L}^{-1}(4 \times)$ applied approximately every 3 weeks by hand with a pressurized sprayer (Table 1). Deionized water was used for preparation of all treatments. SAR-inducing compounds were prepared fresh right before field application. In 2003 plant elicitor treatments were modified and included BTH and BTH+ harpin at rates (at rates similar to 2001). In both years, a control treatment was included.

The potato crop was irrigated and managed for fertility, weeds, and insects and diseases according to recommended practices for potato production in the Pacific Northwest. Soils in each plot were sampled within the root zone using a $2.5 \mathrm{~cm}$ probe to a depth of $30 \mathrm{~cm}$. Soil samples were passed through a $2-\mathrm{mm}$ screen, and then stored at $4{ }^{\circ} \mathrm{C}$ until analysis. Soil texture was determined using the hydrometer method (Gee and Bauder 1986). Soil reaction $(\mathrm{pH})$ was determined by the $1: 1$ soil-water method (Thomas 1996). Total soil $\mathrm{C}$ and $\mathrm{N}$ were determined by dry combustion on duplicate subsamples obtained on the first sampling date from each treatment using a LECO CNS analyzer, model 2000. Microbial biomass C (Jenkinson and Powlson 1976), root zone respiration (Zibilske 1994), 
Table 1. Application of plant elicitors (BTH and harpin) and sample dates of soil microbial populations and activities

\begin{tabular}{lcc}
\hline Crop year & Application & Sampled \\
\hline 2002 & - & 25 May 02 \\
& 11 Jun 02 & 25 Jun 02 \\
& 9 Jul 02 & 24 Jul 02 \\
& 6 Aug 02 & - \\
& - & 22 Oct 02 \\
2003 & - & 2 May 03 \\
& 16 Jun 03 & - \\
& 7 Jul 03 & 28 Jul 03 \\
& 28 Jul 03 & - \\
& 18 Aug 03 & 2 Sept 03 \\
& - & 18 Oct 03 \\
\hline
\end{tabular}

${ }^{a}$ Only bacterial populations counted.

$\mathrm{N}$ mineralization, and microbial populations were determined three times in 2002 and four times in 2003. Microbial biomass C was determined for soil samples using the chloroform fumigation-incubation method described by Jenkinson and Powlson (1976). Respiration was determined by incubating duplicate 25 -g moist-sieved samples from the root zone $(0-20 \mathrm{~cm}$ depth increment) of each field replicate. Samples were adjusted to $60 \%$ of field capacity and incubated in $60 \mathrm{~mL}$ bottles in the dark at $25^{\circ} \mathrm{C}$ for $21 \mathrm{~d}$. Headspace $\mathrm{CO}_{2}$ was measured using an infrared gas analyzer (ADC model) at 3-day intervals through the 21-day incubation. Following each interval of $\mathrm{CO}_{2}$ analysis, the headspace was returned to ambient $\mathrm{CO}_{2}$ by degassing with compressed air. Soil $\mathrm{N}$ mineralization potentials were measured by incubating 10-g soil samples from each treatment replicate in $60 \mathrm{~mL}$ bottles over 21 days at $25^{\circ} \mathrm{C}$, adjusted to $60 \%$ of field capacity. Bottles were opened weekly to reduce the potential of generating anaerobic conditions. Incubated soil was extracted with $50 \mathrm{~mL}$ of $1 \mathrm{M} \mathrm{KCl}$, shaken on a rotary shaker for $1 \mathrm{~h}$, and then filtered through a type A/E glass-fiber filter (Gelman Sciences, Inc., Ann Arbor, Michigan). The $\mathrm{NO}_{3}-\mathrm{N}$ and $\mathrm{NH}_{4}-\mathrm{N}$ in the extracts were determined on an FIA Series auto-analyzer. Populations of culturable aerobic soil and rhizoplane bacteria were enumerated on $0.3 \%$ tryptic soy agar, where Pseudomonas populations were isolated on King's B agar by serial dilution. Soil subsamples $(250 \mathrm{~g})$ were processed via an elutriator and the sugar flotation technique to extract both free-living and plantparasitic nematodes from each treatment; prior to planting, midseason, and harvest in 2002; and prior to planting and harvest in 2003. Nematode species were identified under the microscope, and nematode abundance determined. Prior to harvest, potato roots were scored for Rhizoctonia solani root 
rot and tubers for the presence of sclerotia and nematode damage by sampling four plants in each plot. Potatoes were harvested from $6 \mathrm{~m}$ lengths of the center two rows of each plot.

\section{RESULTS AND DISCUSSION}

\section{Soil Characteristics}

The experiments were conducted in 2002 and 2003 in different 0.4-ha blocks within the same 2-ha field (Table 2). It was known from previous spatial variability studies that surface soil properties varied within this field. Compared to the experimental area in 2002, the experimental area in 2003 had higher sand $(+8 \%)$ and lower silt $(-6.1 \%)$ and clay $(-2.2 \%)$, lower $\mathrm{C}$ and $\mathrm{N}$ contents $(1.3$ and $0.16 \mathrm{~g} \mathrm{~kg}^{-1}$ soil lower, respectively), and higher $\mathrm{pH}$ (8.0 versus 7.6). The site had been cropped to small grains, alfalfa, corn, sugar beets and a variety of vegetable crops and water applied by furrow irrigation since 1925. Cropping system and erosion induced by furrow irrigation are likely contributors to the variation.

\section{Microbial Characteristics}

Culturable bacteria or Pseudomonas populations did not vary for any of the treatments in either year of the study (Figure 1). Foliar applications of both BTH and harpin had no stimulatory or inhibitory effects on the bacterial populations enumerated. In general, bacterial populations increased in the rhizosphere as the season progressed (data not shown) but were lower in both the rhizosphere and on the rhizoplane of potato in 2003 compared to 2002. Rhizosphere aerobic culturable bacterial populations averaged an order of magnitude lower $\left(1.6 \times 10^{6}\right)$ in 2003 compared to the treatments in 2002 $\left(5.0 \times 10^{7}\right)$. Rhizosphere populations of Psuedomonas and fluorescent Psuedomonas showed no response to the plant elicitors. Rhizoplane populations were 100-fold greater than the rhizosphere but, like the rhizosphere populations, did not show a response to either BTH or harpin. The smaller populations in both the rhizosphere and on the rhizoplane in 2003 compared to 2002 were attributed to the lower organic matter reserves present in each of the plots.

Microbial biomass $\mathrm{C}$ in the root zone of potato was not significantly different among the foliar treatments of BTH and harpin at any sampling date, except for the $4 \times$ harpin treatment in 2002, which showed a $35 \%$ reduction (Figure 2). Respiration (Figure 3) and N-mineralization (Figure 4) mirrored the response of the microbial biomass as well as the differences in organic $\mathrm{C}$ reserves between years. Respiration was significantly lower in the 2003 treatments prior to planting and at harvest compared to the 2002 treatments. Mid season microbial biomass, respiration, and $\mathrm{N}$-mineralization increased in the 
Table 2. Soil characteristics of plots treated with BTH and harpin

\begin{tabular}{|c|c|c|c|c|c|c|c|c|}
\hline \multirow[b]{2}{*}{ Year } & \multirow[b]{2}{*}{ Treatment } & \multicolumn{3}{|c|}{ Particle size fractions $(\%)$} & \multicolumn{2}{|c|}{ Total $\left(\mathrm{g} \mathrm{kg}^{-1}\right.$ soil $)$} & \multirow[b]{2}{*}{ C:N } & \multirow[b]{2}{*}{$\mathrm{pH}$} \\
\hline & & Sand & Silt & Clay & Carbon & Nitrogen & & \\
\hline \multicolumn{9}{|l|}{2002} \\
\hline & Control & $64.1(5.1)$ & $28.3(4.4)$ & $7.6(1.1)$ & $5.6(0.9)$ & $0.55(0.1)$ & 10.9 & $7.6(0.3)$ \\
\hline & BTH & $62.2(6.6)$ & $30.2(5.6)$ & $7.7(1.3)$ & $6.4(0.8)$ & $0.62(0.1)$ & 10.3 & $7.4(0.3)$ \\
\hline & Harpin & $66.7(4.0)$ & $25.1(3.7)$ & $8.3(3.4)$ & $6.1(0.8)$ & $0.61(0.1)$ & 11.0 & $7.8(0.3)$ \\
\hline & Harpin 4X & $57.8(4.3)$ & $33.1(3.4)$ & $9.1(1.1)$ & $5.7(0.3)$ & $0.62(0.1)$ & 9.2 & $7.8(0.3)$ \\
\hline & Field average & $62.8(4.5)^{*}$ & $29.2(3.8)$ & $8.0(1.1)^{*}$ & $6.0(0.7)^{*}$ & $0.60(0.1)^{*}$ & 10.5 & $7.6(0.2)^{*}$ \\
\hline \multicolumn{9}{|l|}{2003} \\
\hline & Control & $68.0(4.9)$ & $24.9(3.4)$ & $7.1(1.5)$ & $4.2(0.9)$ & $0.36(0.1)$ & 12.8 & $8.0(0.2)$ \\
\hline & BTH & $74.8(4.7)$ & $20.5(4.0)$ & $5.7(2.5)$ & $4.3(0.9)$ & $0.48(0.1)$ & 11.5 & $7.9(0.4)$ \\
\hline & BTH + Harpin & $70.4(4.7)$ & $23.9(3.3)$ & $4.7(0.9)$ & $5.3(1.6)$ & $0.44(0.1)$ & 10.4 & $8.0(0.2)$ \\
\hline & Field average & $71.1(3.9)^{*}$ & $23.1(2.9)$ & $5.8(1.1)^{*}$ & $4.7(0.7)^{*}$ & $0.44(0.1)^{*}$ & 11.3 & $8.0(0.1)^{*}$ \\
\hline
\end{tabular}

Note: Values in parentheses are standard error of the mean. Asterisks indicate significant differences between the two years. 

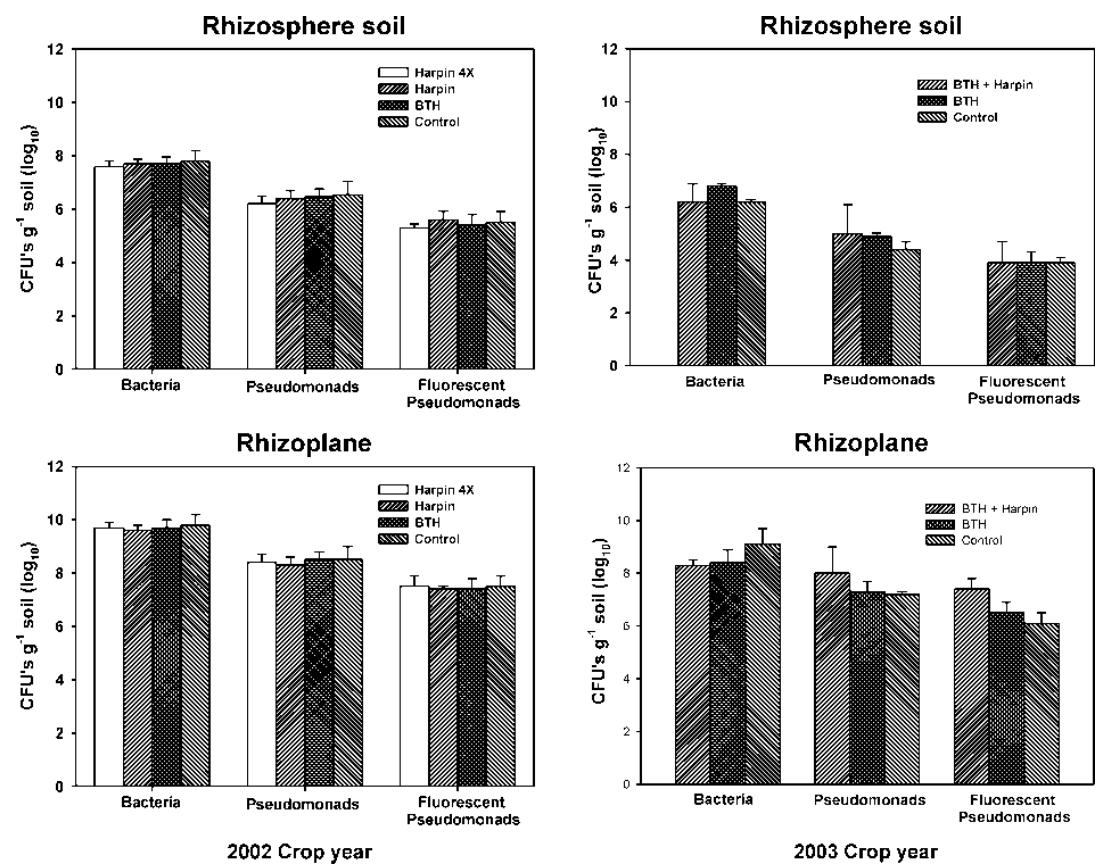

Figure 1. Bacterial populations in the rhizosphere and rhizoplane of potato treated with BTH and harpin during the 2002 and 2003 crop years.

root zone of potato resulting from an increase in root exudates as the potato plants matured but showed no effect from the foliar treatments.

Rhizoctonia root rot was present in all plots both years (Table 3). Applications of BTH and harpin showed a trend in lowering root infection (23\%), where the $4 \times$ harpin treatment showed an increase $(18 \%)$ above the control. In addition, the numbers of sclerotia per tuber were reduced significantly only in the $4 \times$ harpin treatment compared to the control.

\section{Nematodes}

Population densities of non-plant-parasitic (free-living) lesion and root-knot nematodes extracted from potato rhizospheres are shown in Figure 5. Nonplant-parasitic nematodes increased in the harpin treatments and decreased with BTH compared to the control. All SAR treatments resulted in a reduction of lesion nematodes (Pratylenchus spp.) but had no significant effect on the numbers of root-knot nematodes (Meloidogyne chitwoodi). Infection was severe in both years as $85 \%$ of tubers showed root-knot nematode damage (Table 3). High variability in nematode densities (ranging from 0 to 3000 per $250 \mathrm{~g}$ of soil) have been measured in the 2-ha field 

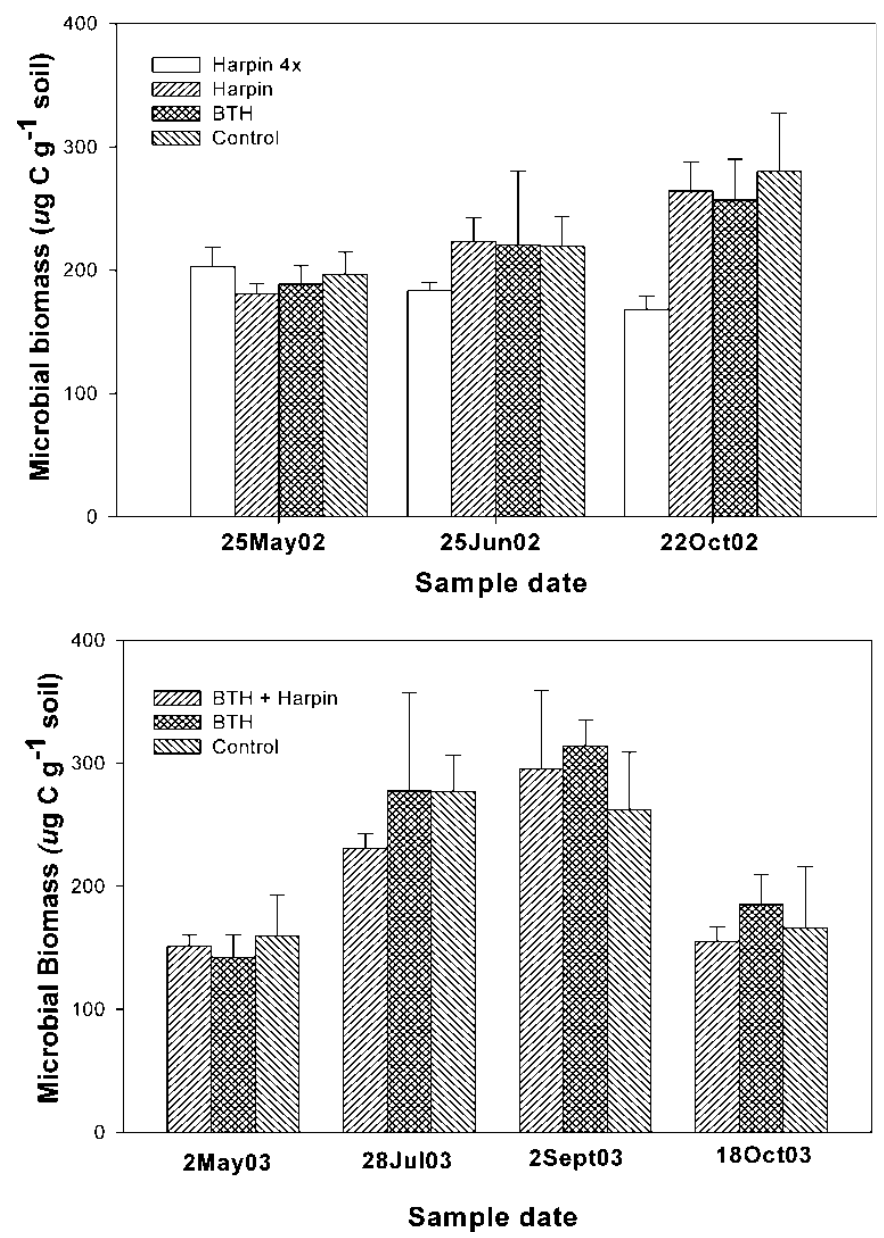

Figure 2. Microbial biomass $\mathrm{C}$ in the rhizosphere of potato treated with $\mathrm{BTH}$ and harpin during the 2002 and 2003 crop years. Error bars at $p=0.05$.

(E. Riga, personal communication). We know from periodic spatial sampling that nematode densities have increased in this field since they were first measured in the spring of 2002 through the last spatial sampling in the fall of 2004 (Riga, personal communication). Population density increases are likely due to the cropping of nematode host plants (wheat, corn) in the absence of nematicide treatments. It is not clear how high plant parasitic nematode densities may have influenced the efficacy of the plant elicitors.

Although the plant elicitors did not significantly reduce the lesion nematode, in the beginning and middle of the potato cropping season of 2002 , the $4 \times$ harpin treatment exhibited a significant reduction in lesion nematodes at the end of the season compared to the control (Figure 5). In 

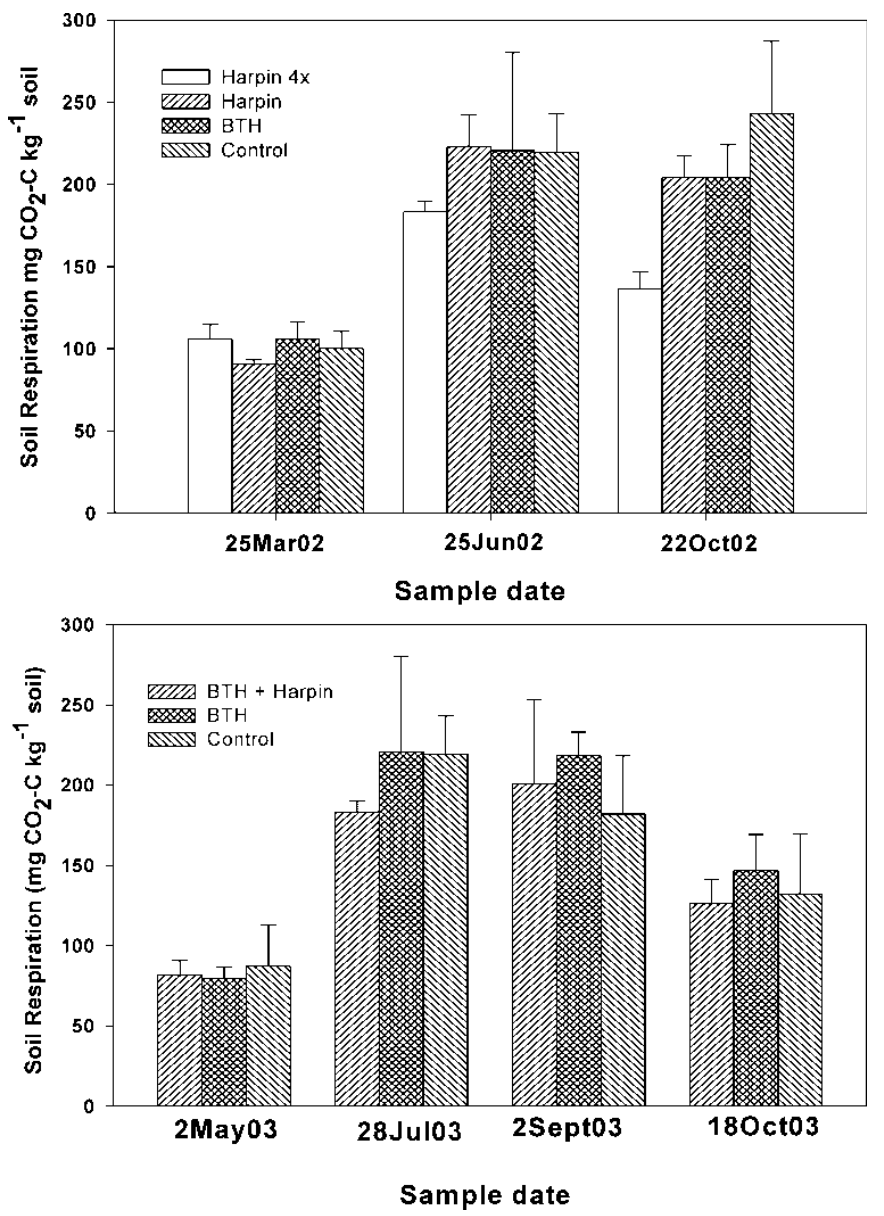

Figure 3. Soil respiration in the root zone of potato treated with BTH and harpin during the 2002 and 2003 crop years. Error bars at $\mathrm{p}=0.05$.

addition, BTH reduced lesion nematodes at the end of the season. BTH significantly reduced the root-knot nematodes at the end of the season. Harpin also showed a reduction in root-knot nematodes at the end of the season; however, that reduction was not significantly different than the control. In addition, BTH and harpin $4 \times$ reduced the nematode infection index $23 \%$ in comparison to the control. All plant elicitors reduced the percentage of culled potatoes in comparison to the control. The plant elicitors tended to increase the population densities of nontarget free-living nematodes in the soil in comparison to the control. We hypothesize that the efficacy of the plant elicitors will be increased reducing plant-parasitic nematode densities and protecting potato tubers from nematode infection, if the plant-parasitic nematode densities are low to moderately high. However, although there was a significant trend to 

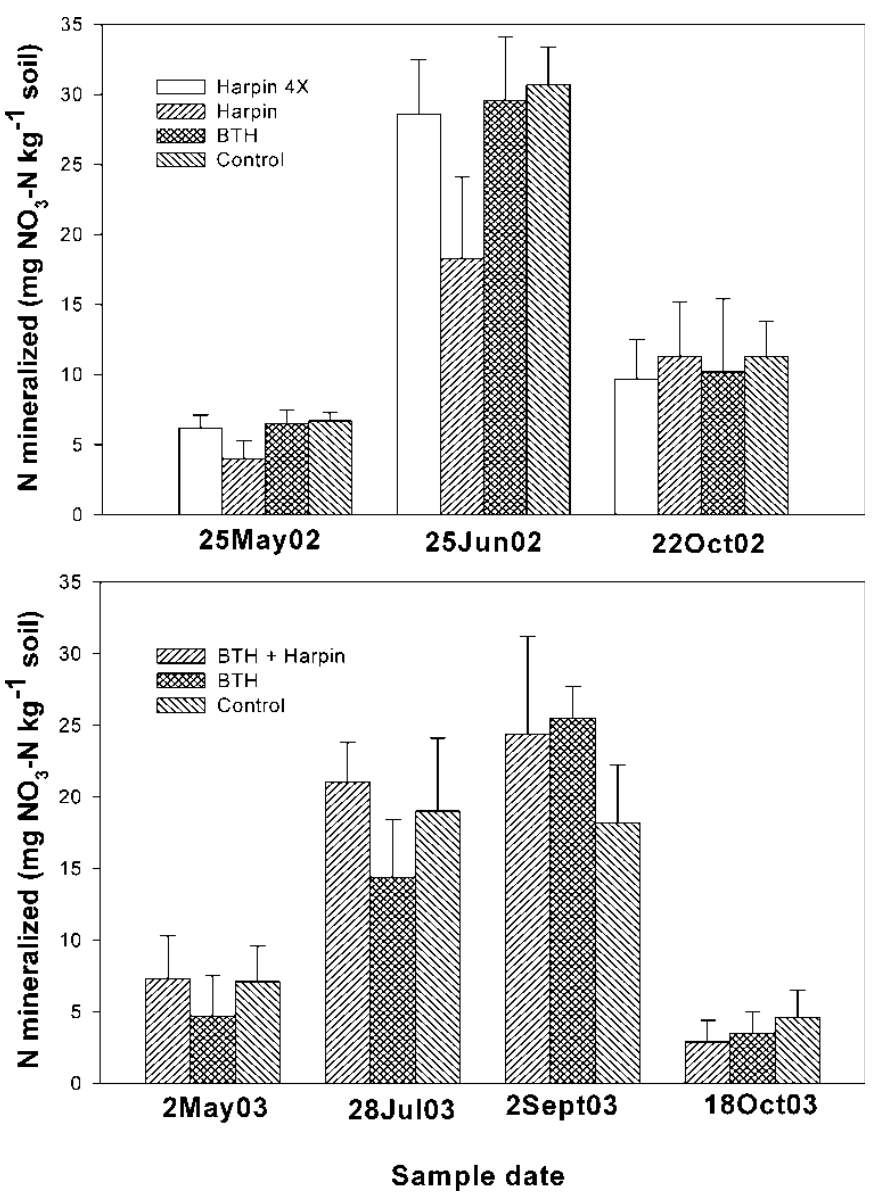

Figure 4. N-mineralization after 21 days in the root zone of potato treated with BTH and harpin during the 2002 and 2003 crop years. Error bars at $\mathrm{p}=0.05$.

reduce nematodes in the field, the very high nematode densities significantly reduced the marketable yield and was considered a significant challenge for the two plant elicitors to overcome.

\section{CONCLUSIONS}

Under field conditions, the effect of foliar applications of the plant elicitors of BTH and harpin was determined on soil microbial populations, a soil-borne fungal pathogen (Rhizoctonia solani), free-living and plant-parasitic nematodes, soil respiration, and $\mathrm{N}$ mineralization potentials under potato production. Broad-scale properties such as microbial biomass $\mathrm{C}$, total culturable bacterial, respiration, and $\mathrm{N}$ mineralization potentials were generally not different 
Table 3. Percent of potato roots infected with Rhizoctonia root rot (Rhizoctonia solani), numbers of sclerotia per tuber, and root knot nematode (Meloidogyne chitwoodi) infection ratings for plots treated with the plant elicitors BTH and harpin

\begin{tabular}{lcccccc}
\hline Treatment & $\begin{array}{c}\text { Rhizoctonia } \\
\text { infection }^{a}(\%)\end{array}$ & $\begin{array}{c}\text { Number of sclerotia } \\
\text { per tuber }\end{array}$ & $\begin{array}{c}\text { Nematode } \\
\text { infection index }\end{array}$ & $\begin{array}{c}\text { Average cull } \\
\text { potatoes }(\%)\end{array}$ & $\begin{array}{c}2002 \text { yield } \\
\left(\mathrm{Mg} \mathrm{ha}^{-1}\right)\end{array}$ & $\begin{array}{c}2003 \text { yield } \\
\left(\mathrm{Mg} \mathrm{ha}^{-1}\right)\end{array}$ \\
\hline Control & 17.2 & 3.0 & $3.4(0.7)$ & $73.8(14.8)$ & $75.4(6.1)$ & $56.2(1.0)$ \\
BTH & 13.9 & 2.8 & $2.6(0.6)$ & $54.4(13.1)^{*}$ & $70.7(4.7)$ & $58.7(5.1)$ \\
Harpin & 15.7 & 2.9 & $3.4(0.9)$ & $67.5(16.9)$ & $70.8(3.8)$ & $49.8(2.6)^{*}$ \\
Harpin $4 \mathrm{X}$ & 20.1 & $2.5^{*}$ & $2.8(1.0)$ & $57.5(17.9)^{*}$ & $76.7(8.3)$ & NS \\
$\mathrm{p}=.05$ & $\mathrm{NS}$ & $*$ & $\mathrm{NS}$ & $*$ & $*$ \\
\hline
\end{tabular}

${ }^{a}$ Percent of roots infected prior to harvest.

${ }^{b}$ Number of sclerotia per tuber, estimated as a visual score on a $1-5$ scale $(1=0-10 ; 2=11-100 ; 3=101-1000$; $4=1001-5000 ; 5=>5000)$.

${ }^{c}$ Nematode infection index determined by a visual score on a $1-6$ scale $(1=1-3 ; 2=4-5 ; 3=6-9 ; 4=10+; 5=50+$; $5=100+)$

Values in parentheses are standard error of the mean.

*Significant difference at $\mathrm{p}<0.05$ 

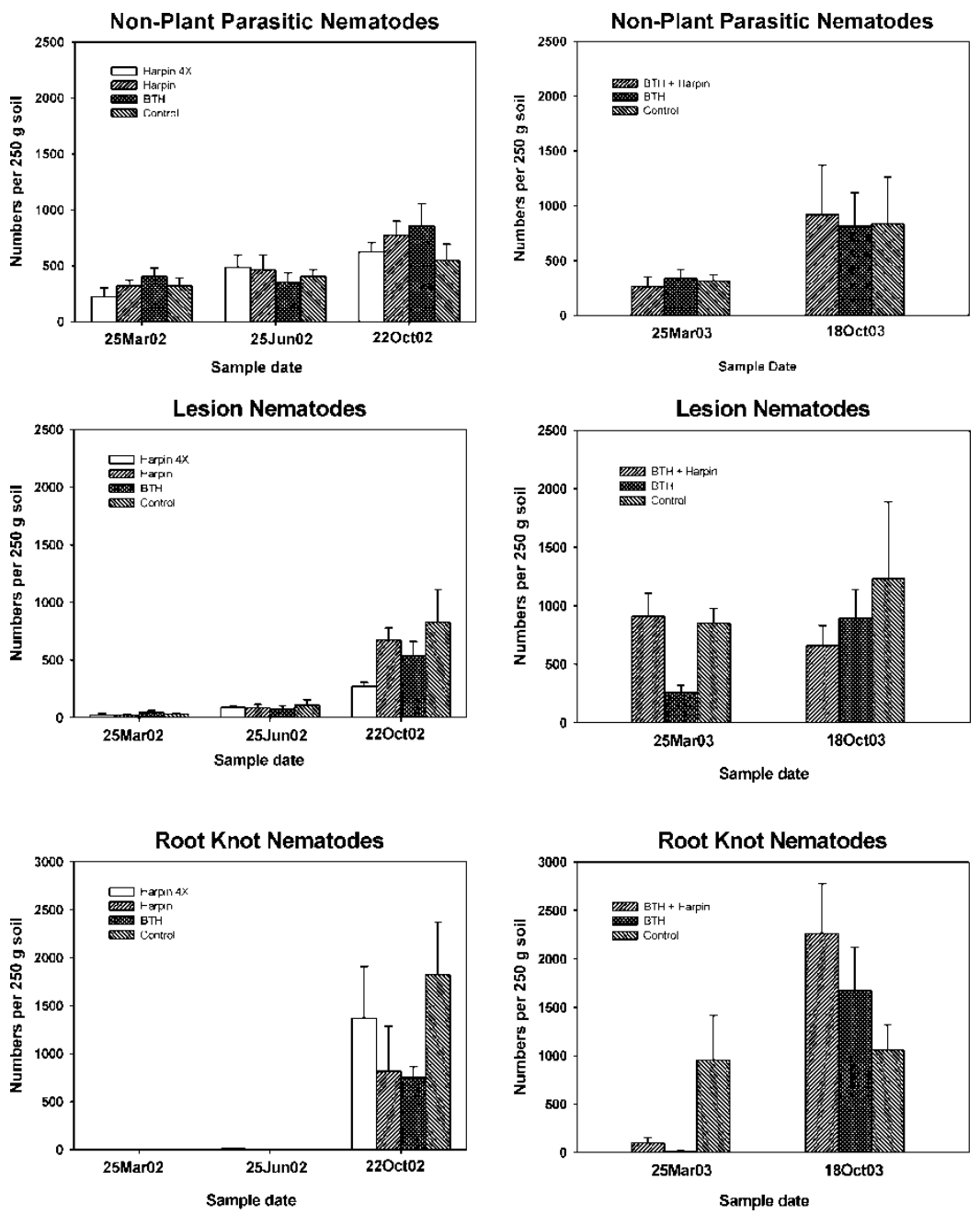

Figure 5. Nematode populations in the rhizosphere of potato treated with BTH and harpin during the 2002 and 2003 crop years. Lesion: Pratylenchus spp.; root knot: Meloidogyne chitwoodi.

between the treatments. The plant elicitors used in this study did not have a negative impact on microbial populations or their activities, as has been shown for some pesticides used to control pathogenic fungi and nematodes. Further study is needed to determine if these plant elicitors have any direct effect on soil microbial diversity inhabiting the rhizosphere and identify if plants with active defense pathways alter carbon flow and root exudates into the soil. 


\section{ACKNOWLEDGMENTS}

This research was supported, in part, by funding from the Center for Precision Agriculture, Washington State University, Prosser, Washington. The authors thank M. Seymour (USDA-ARS, Prosser, Washington) and J. Wilson (Washington State University) for field assistance, and W. Boge and R. Cochran (USDA-ARS, Prosser, Washington) and M. Lauer (Washington State University) for sample processing and laboratory analyses.

\section{REFERENCES}

Abbasi, P.A., Al-Dahman, J., Sahin, F., Hoitink, H.A.J., and Miller, S.A. (2002) Effect of compost amendments on disease severity and yield of tomato in conventional and organic production systems. Plant Disease, 86: 156-161.

Csinos, A.S., Pappu, H.R., McPherson, R.M., and Stephenson, M.G. (2001) Management of tomato spotted wilt virus in flue-cured tobacco with acibenzolar-S-methyl and imidacloprid. Plant Disease, 85: 292-296.

Dempsey, D., Shah, J., and Klessig, D.F. (1999) Salicylic acid and disease resistance in plants. Critical Reviews in Plant Science, 18: 547-575.

Gee, G.W. and Bauder, J.W. (1986) Particle-size analysis. In Methods of Soil Analysis, Part 1: Physical and Mineralogical Methods; Klute, A. (ed.); Soil Science Society of America: Madison, Wisconsin, 383-409.

Gozzo, F. (2003) Systemic acquired resistance in crop protection: From nature to a chemical approach. Journal of Agriculture and Food Chemistry, 51: 4487-4503.

Jenkinson, D.S. and Powlson, D.S. (1976) The effects of biocidal treatments on metabolism in soil, I: Fumigation with chloroform. Soil Biology and Biochemistry, 8: $167-177$.

Klessig, D.F., Durner, J., Noad, R., Navarre, D.A., Wendehenne, D., Kumar, D., Zhou, J.M., Shah, J., Zhang, S., Kachroo, P., Trifa, Y., Pontier, D., Lam, E., and Silva, H. (2000) Nitric oxide and salicylic acid signaling in plant defense. Proceedings of National Academy of Science, 97 (16): 8849-8855.

Lawton, K., Fredrich, L., Hunt, M., Weymann, K., Delaney, T., Kessman, H., Staub, T., and Ryals, J. (1996) Benzothiadiazole induces disease resistance in Arabidopsis by activation of the systemic acquired resistance signal transduction pathway. Plant Journal, 10: 71-82.

Matheron, M.E. and Porchas, M. (2002) Suppression of pythophthora root rot and crown rot on pepper plants treated with acibenzolar-S-methyl. Plant Disease, 86: 292-297.

Sticher, L., Mauch-Mani, B., and Metraux, J.-P. (1997) Systemic acquired resistance. Annu. Rev. Phytopathol., 35: 235-270.

Thomas, G.W. (1996) Soil pH and soil activity. In Methods of Soil Analysis, Part 3: Chemical Methods; Bartels, J.M. (ed.); Soil Science Society of America: Madison, Wisconsin, 475-490.

Vallad, G.E. and Goodman, R.M. (2004) Systemic acquired resistance and induced systemic resistance in conventional agriculture. Crop Science, 44: 1920-1934.

Zibilske, L.M. (1994) Carbon mineralization. In Methods of Soil Analysis, Part 2: Microbiological and Biochemical Properties; Mickelson, S.H. (ed.); Soil Science Society of America: Madison, Wisconsin, 835-864. 